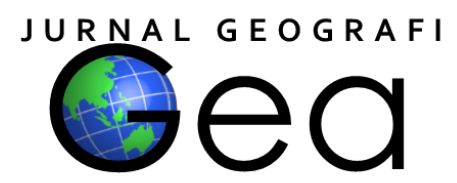

\title{
SPATIAL AND TEMPORAL ANALYSIS OF DISSOLVED OXYGEN (DO) AND BIOLOGICAL OXYGEN DEMAND (BOD) CONCENTRATIONS IN RAWA PENING LAKE, SEMARANG REGENCY
}

\author{
Muhammad Handoko ${ }^{1}$, Alfred Jansen Sutrisno ${ }^{2}$ \\ ${ }^{1,2}$ Agrotechnology Study Program, Faculty of Agriculture and Business, Universitas Kristen \\ Satya Wacana, Salatiga \\ 1512016013@student.uksw.edu, ${ }^{2}$ fpb.alfred@uksw.edu
}

\begin{abstract}
Rawa Pening Lake are the waterbody which it waters comes from a swamp spring, besides that several rivers empty into Rawa Pening, including Galeh River, Torong River, Panjang River, Muncul River, Parat River, Legi River, Pitung River, Praginan River, and Rengas River. Three problems cause damage to the Rawa Pening Lake ecosystem, namely damage to the water catchment area, damage to the lake border, and water pollution. This study aims to analyze Dissolved Oxygen (DO) and Biological Oxygen Demand (BOD) spatially and temporally due to damage to the lake ecosystem. The method used was Inverse Distance Weighted (IDW), where 12 sample point locations were taken, 10 sample points representing each village (lake inlet and utilization), and 2 sample points representing the center and outlet of the lake. The average DO yield in September 2020 was $6.8 \mathrm{mg} / \mathrm{L}$, then in October 2020 it was $4.65 \mathrm{mg} / \mathrm{L}$ and in November 2020 it was $3.04 \mathrm{mg} / \mathrm{L}$. Then the average BOD in September 2020 was $3.16 \mathrm{mg} / \mathrm{L}$, then in October 2020 it was $2.6 \mathrm{mg} / \mathrm{L}$ and in November it was $1.53 \mathrm{mg} / \mathrm{L}$, so it can be seen that the DO variable and BOD both decreased from September to November 2020.

Keywords: Biological Oxygen Demand, Dissolved Oxygen, Distribution SpatialTemporal, Inverse Distance Weighted
\end{abstract}

\section{INTRODUCTION}

Rawa Pening is a natural lake that is dammed for irrigation purposes with 1 river that comes out (outlet) namely Tuntang and 9 rivers that flow into the lake (inlet). Some of the tributaries that enter Rawa Pening include Galeh Sub-Watershed, Torong, Panjang, Legi, Parat, Sraten, Rengas, Kedung Ringin and Ringis. Rawa Pening is located in Semarang Regency, Central Java, bordered by four subdistricts namely Ambarawa, Tuntang, Bawen, and Banyubiru (Department of Animal Husbandry and Fisheries, Semarang, 2007).
The condition of public waters in some lakes has decreased or degraded, such as in Rawa Pening Lake. This degradation is caused by exploitation and excessive utilization (Zulfia and Aisha, 2013). Such utilization is related among others for commercial or recreational purposes of fisheries, the level of exploitation to meet the needs of fish protein or aesthetic services, as well as socio-economic aspects (Cowx, 2002). Until now, the community around Rawa Pening lake uses the existence of the lake to meet the needs of food and family income sources, including fisheries 
businesses, peat miners, water hyacinth, and agriculture. The life of an organism in the water depends largely on the quality of the water in which it lives. Good water quality strongly supports the growth of aquatic organisms, both animals and plants. Water quality is one of them seen in terms of chemistry, where chemical elements in water serve as carriers of nutrients, minerals, and gases dissolved in water such as DO. Changes in DO concentration within certain limits also indicate a change in water quality, the lower the concentration the lower the quality of the water. Decreased concentration of $\mathrm{O} 2$ will decrease the physiological activity of living creatures in water (Susana, 2009). DO is the concentration of oxygen dissolved in water. The availability of DO in water determines the life of shrimp and fish. The presence of DO is essential for maintaining various forms of biological life in water (Effendi et al., 2015). Oxygen plays an important role as an indicator of water quality, as DO plays a role in the oxidation and reduction processes of organic and inorganic matter. Besides oxygen also determines the biological khan performed by aerobic or anaerobic organisms (Salmin, 2005). While BOD is a measure of the amount of oxygen used by microorganisms to decompose organic matter in water in five days (Effendi et al., 2015). Also, BOD parameters, in general, are widely used to determine the level of wastewater pollution. Determination of BOD is very important to trace the flow of pollution from the upstream level to the estuary. Indeed, the determination of BOD is a bioassay procedure that concerns the measurement of the amount of oxygen used by the organism as long as the organism decomposes the organic matter present in water, under almost the same conditions as the conditions in nature. Impact, high low DO and BOD is very influential on floating net cage fish and fishing activities; therefore, it is necessary to provide recommendations on the standard status of water quality of Rawa Pening Lake spatially and temporally.

This research needs to be done to analyze the quality of water spatially and temporally, caused by land use around Rawa
Pening Lake. The steps taken for this study are, firstly analyzing water quality based on DO and BOD parameters using PDO-519 tools, secondly interpolating do and BOD water quality results by class in September, October, and November using one of the spatial interpolation methods which are weighted reverse distance. Inverse Weighted Distance (IDW) is an interpolation method commonly used in spatial interpolation analysis (Yaxin et al., 2012). In the IDW method, it is assumed substantially that the degree of correlation and similarity between neighbors is proportional to the distance between them which can be defined as a function of the recoil distance from each point of the neighboring point (Agung and Tamia, 2013). The Weighted Inverse Distance of this method is used to predict the value of a point to know using the values of a known point (Xie et al., 2011). The third is to create a standard spatial distribution map of water quality using Geographic Information System (SIG), which is a computer-based spatial information system involving ArcGIS 10.4 software.

\section{RESEARCH METHODS \\ Research Location and Time}

The research was conducted in August November 2020 at Rawa Pening Lake, Semarang Regency, Central Java. Rawa Pening is located in Semarang Regency, Central Java, bordered by four sub-districts, namely Ambarawa, Tuntang, Bawen and Banyubiru. The area is located in a geographical position between $7^{\circ} 4^{\prime}-7^{\circ} 30^{\prime \prime} \mathrm{LS}$ and $110^{\circ} 24^{\prime} 46^{\prime \prime}-110^{\circ} 49^{\prime} 06^{\prime \prime} \mathrm{E}$ (Figure 1) and is at altitudes between 455-465 meters above sea level (dpl) and is surrounded by three mountains: Merbabu, Telomoyo, and Ungaran (Fadilah et al., 2018). The Ministry of Environment (2011) stated that the benefits of Rawa Pening Lake are for land fishery activities both natural fisheries and aquaculture fisheries, tidal rice fields, and handicraft raw materials from water hyacinth. The research location of Rawa Pening Lake can be seen in figure 1 . 


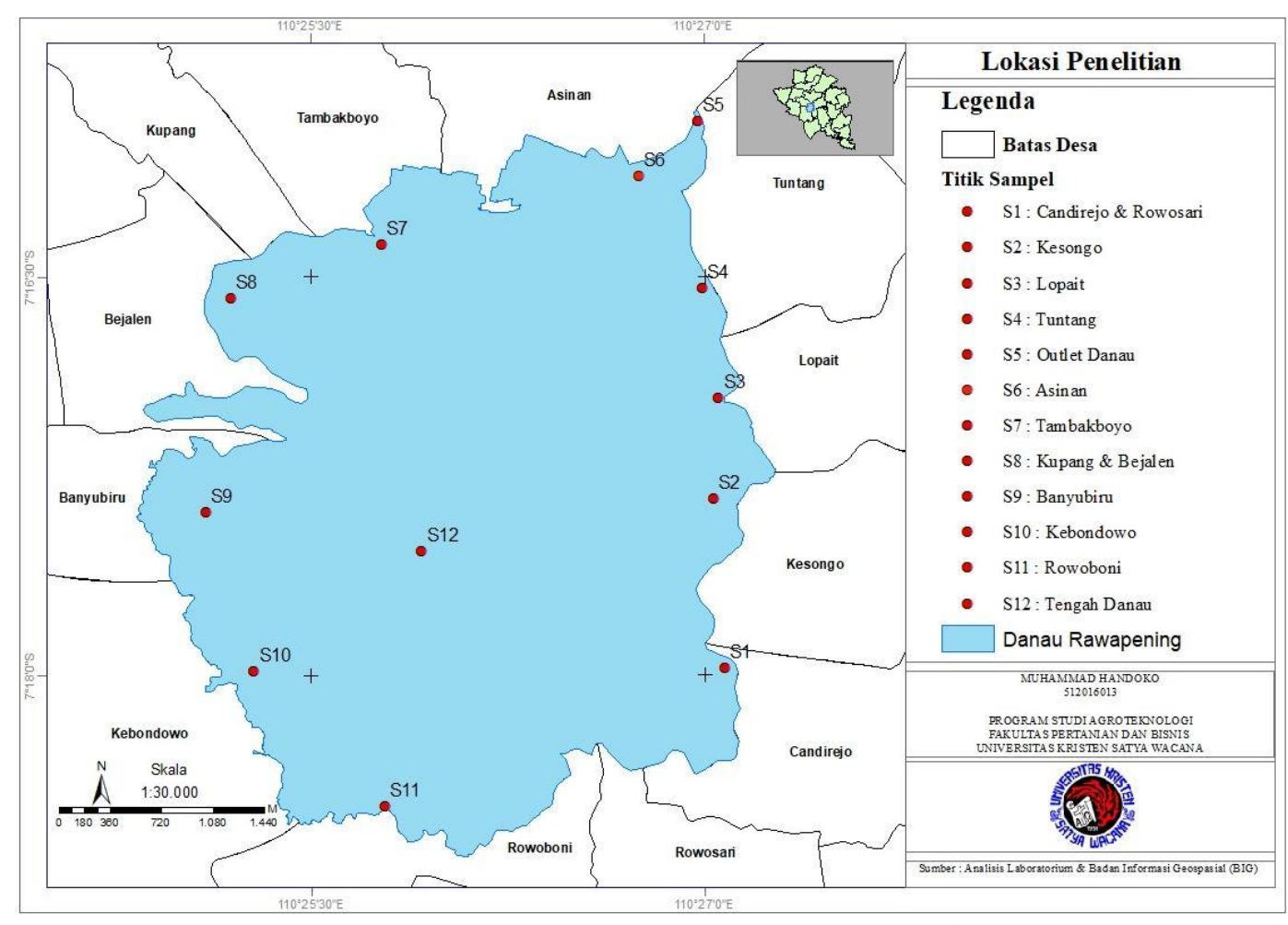

Figure 1. Research Site in Rawapening Lake

Population and Research Samples

Sampling took 12 sample points, 10 sample points representing each village (inlet and lake utilization) and 2 sample points representing the middle and outlet of the lake. Where sampling and monitoring of water quality in Rawa Pening Lake is based on SNI 6989.57:2008; where the river enters the lake/reservoir, in the middle of the lake/reservoir, the location of water tapping for utilization and the place of discharge of lake water/reservoir. Locations for sampling, as well as identification, are done in different places. Determination of sampling location based on consideration and type of activities carried out by the community around Rawa Pening Lake area. The location of the 12 sample point monitoring stations can be seen in Table 1 .

Table 1. Sampling station coordinate location

\begin{tabular}{|c|c|c|c|}
\hline \multirow[t]{2}{*}{ Point } & \multicolumn{2}{|c|}{ Coordinates } & Description \\
\hline & Latitude & Longitude & \\
\hline S1 & $110^{\circ} 27^{\prime} 4.77^{\prime \prime T}$ & $7^{\circ} 17^{\prime} 58.51 " \mathrm{~S}$ & Candirejo and Rowosari \\
\hline S2 & $110^{\circ} 27^{\prime} 2.15^{\prime \prime T}$ & $7^{\circ} 17^{\prime} 20.14^{\prime \prime S}$ & Kesongo \\
\hline S3 & $110^{\circ} 27^{\prime} 3.35^{\prime \prime T}$ & $7^{\circ} 16^{\prime} 57.38^{\prime \prime S}$ & Lopait \\
\hline S4 & $110^{\circ} 26 ' 59.69^{\prime T} \mathrm{~T}$ & $7^{\circ} 16^{\prime} 32.66^{\prime \prime S}$ & Tuntang \\
\hline S5 & $110^{\circ} 26^{\prime} 58.73^{\prime \prime T}$ & $7^{\circ} 15^{\prime} 54.79^{\prime \prime} \mathrm{S}$ & Outlet Danau \\
\hline S6 & $110^{\circ} 26^{\prime} 45.21^{\prime \prime T}$ & $7^{\circ} 16^{\prime} 7.08 " \mathrm{~S}$ & Asinan \\
\hline S7 & $110^{\circ} 25^{\prime} 46.40^{\prime \prime T}$ & $7^{\circ} 16^{\prime} 22.67 " \mathrm{~S}$ & Tambakboyo \\
\hline S8 & $110^{\circ} 25^{\prime} 11.98^{\prime \prime T}$ & $7^{\circ} 16^{\prime} 34.74^{\prime \prime S}$ & Kupang dan Bejalen \\
\hline S9 & $110^{\circ} 25^{\prime} 6.14^{\prime \prime T}$ & $7^{\circ} 17^{\prime} 22.99 " \mathrm{~S}$ & Banyubiru \\
\hline $\mathrm{S} 10$ & $110^{\circ} 25^{\prime} 16.99^{\prime \prime T}$ & $7^{\circ} 17^{\prime} 58.99 " \mathrm{~S}$ & Kebondowo \\
\hline $\mathrm{S} 11$ & $110^{\circ} 25^{\prime} 46.95^{\prime \prime T}$ & $7^{\circ} 18^{\prime} 29.70^{\prime \prime S}$ & Rowoboni \\
\hline $\mathrm{S} 12$ & $110^{\circ} 25^{\prime} 55.34^{\prime \prime T}$ & $7^{\circ} 17^{\prime} 31.85^{\prime \prime S}$ & Tengah Danau \\
\hline
\end{tabular}




\section{Data Collection Methods}

Water sampling techniques are conducted by grab samples, namely the method of sampling directly in the water BODy that is studied and adjusted to SNI 6989.57:2008, about the method of sampling surface water. Sampling for lake water quality measurement which includes chemical conditions namely DO and BOD is measured using PDO-519 Tool, with DO treatment measured directly at Rawa Pening Lake in each station. While the BOD test was conducted in the Chemistry Laboratory of Satya Wacana Christian University, to obtain BOD data, sampling was conducted using a dark bottle measuring $150 \mathrm{ml}$, then stored in a room temperature of about $20{ }^{\circ} \mathrm{C}$ for 5 days, after 5 days measured again using PDO-519. The principle of measurement of BOD is quite simple, namely measuring the initial dissolved oxygen content of DO0 and DO5 then the value of DO0 (first day) minus the value of DO5 (fifth day) is the value of BOD expressed in milligrams of oxygen per liter $(\mathrm{mg} / \mathrm{L})$ (Riyanda,2013). Then measure the DO content in the sample that has been incubated for 5 days, assuming that during that time the percentage of reaction is quite large from the total BOD (Yulis et al., 2018). Incubation serves as sample isolation to see how much DO decreases in water in dark places and temperatures of $20^{\circ} \mathrm{C}$, therefore microorganism activity is limited so that oxygen reduction is minimal (Ardhiani, 2016). The temperature should be kept constant at $20^{\circ} \mathrm{C}$ which is a common temperature in nature. However, in tropical areas such as Indonesia, it could be that the temperature of this incubation is not appropriate. Tropical water temperatures generally range from $25-30^{\circ} \mathrm{C}$, with relatively lower incubation temperatures causing the activity of decomposing bacteria is also lower and not optimal as expected so that in this study obtained a fairly small BOD value that has not described the results of overall oxidation of microorganisms (Yulis et al., 2018).

Data Processing and Analysis Methods Data analysis in this study using spatial interpolation, used to determine the distribution of DO and BOD in Rawa Pening Lake further, the basic principles of spatial interpolation is to create a surface that models the phenomenon of samples in the best way. There are 12 sampling points in this study, points determined by a random distance at which each point represents the use of Rawa Pening Lake. This study uses one of the spatial interpolation methods which is weighted reverse distance. IDW is an interpolation method commonly used in spatial interpolation analysis (Yaxin et al., 2012). In the IDW method, it is assumed substantially that the degree of correlation and similarity between neighbors is proportional to the distance between them which can be defined as a function of the recoil distance from each point of the neighboring point (Agung and Tamia, 2013). Weighted inverse distance This method is used to predict the value of a point to know using the values of a known point (Xie et al., 2011). Where $\mathrm{Z}(\mathrm{x})$ is the value of the point to be known, $\mathrm{n}$ is the number of sample points, $\mathrm{Zi}$ is the value of the known sample point. The distance between the known sample point and the sample point you want to know is at, and you are the weight value based on distance (Sutrisno et al., 2018).

$$
Z(x)=\frac{\sum_{i}^{n}=1 \frac{Z i}{d_{i}^{u}}}{\sum_{i}^{n}=1 \frac{1}{d_{i}^{u}}}
$$




\section{FINDINGS AND DISCUSSION}

Dissolved Oxygen (DO) spatial and temporal distribution DO is the amount of dissolved oxygen in water derived from photosynthesis and atmospheric/air absorption (Sari and Wijaya, 2019). The average DO concentration in September 2020 was $6,8 \mathrm{mg} / \mathrm{L}$ with maximum concentrations of $9,6 \mathrm{mg} / \mathrm{L}$ in Candirejo, Rowosari (S1), Kesongo (S2), and Banyubiru (S9). The minimum concentration is $2 \mathrm{mg} / \mathrm{L}$ in Kebondowo (S10).
Based on the classification of water quality is determined into four classes, namely class I used for drinking raw water, class II is used for water infrastructure / recreational facilities, class III is used for freshwater fish cultivation and animal husbandry, and class IV is used to irrigate crops. From Figure 2 it appears that the DO score in September, there are 8 points included in class I, 3 points including class II, and 1 point including class IV.

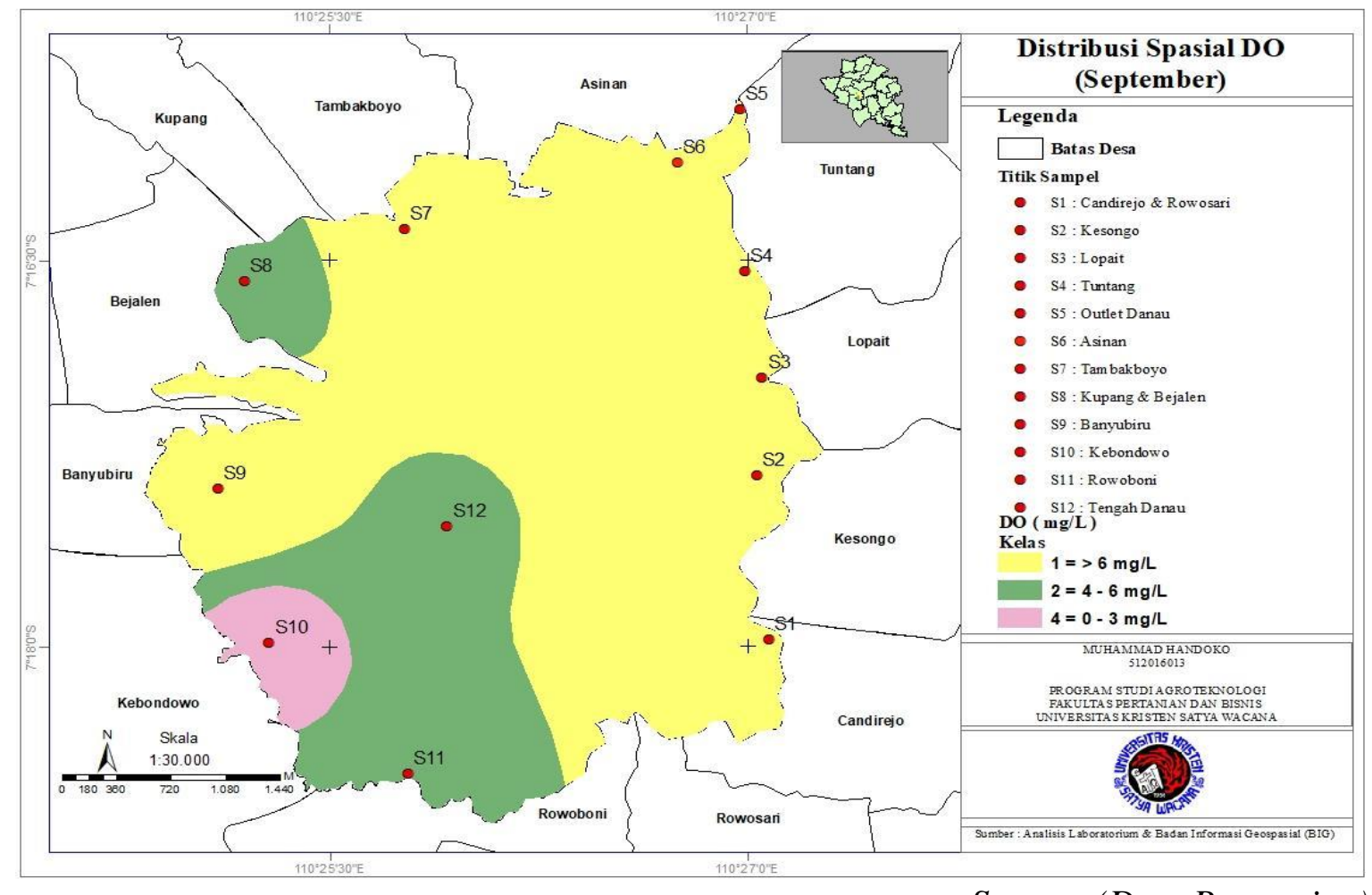

Source: (Data Processing)

Figure 2. Results of Dissolved Oxygen (DO) Spatial Distribution in September

As of October 2020, the average DO concentration has decreased from $6.8 \mathrm{mg} / \mathrm{L}$ in September to $4.65 \mathrm{mg} / \mathrm{L}$ in October, with a maximum concentration of $9.7 \mathrm{mg} / \mathrm{L}$ in Candirejo and Rowosari (S1) and a minimum concentration of $1.0 \mathrm{mg} / \mathrm{L}$ in
Tuntang (S4). From Figure 3 it appears that the DO score in October, there are 4 points including class I, 2 points including class II, 1 point including class III, and 5 points including class IV. 


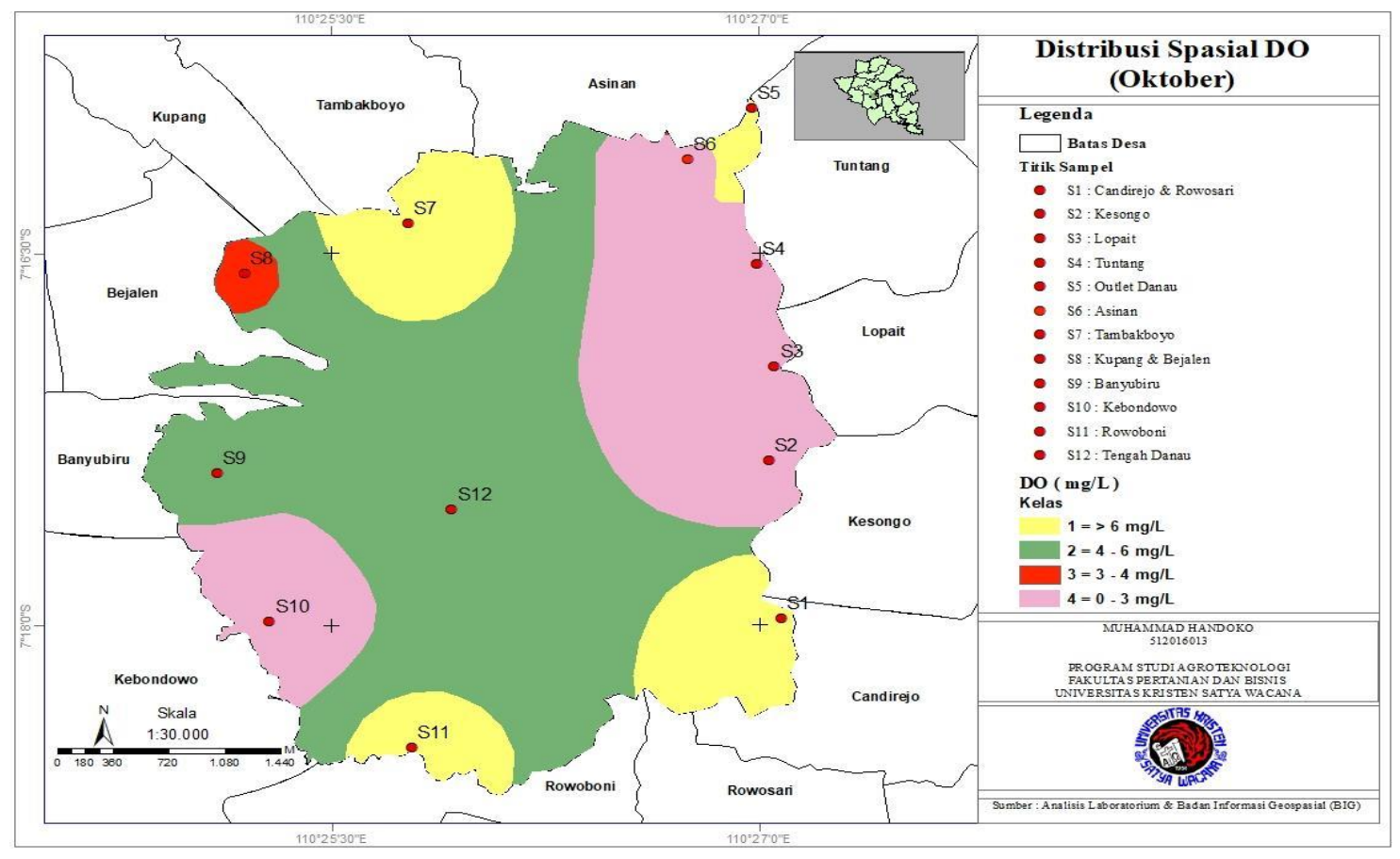

Source: (Data Processing)

Figure 3. Results of Dissolved Oxygen (DO) Spatial Distribution in October

The average DO in November at each station did not include class I and decreased. The average DO has decreased from 4.65 $\mathrm{mg} / \mathrm{L}$ in October to $3.04 \mathrm{mg} / \mathrm{L}$ in November, with a maximum concentration of $5.4 \mathrm{mg} / \mathrm{L}$ in Rowoboni (S11) and a minimum concentration of $0.9 \mathrm{mg} / \mathrm{L}$ in Kesongo (S2). From Figure 4 it appears that the DO score in November, there are 3 points included in class II, 3 points including class III, and 6 points including class IV.

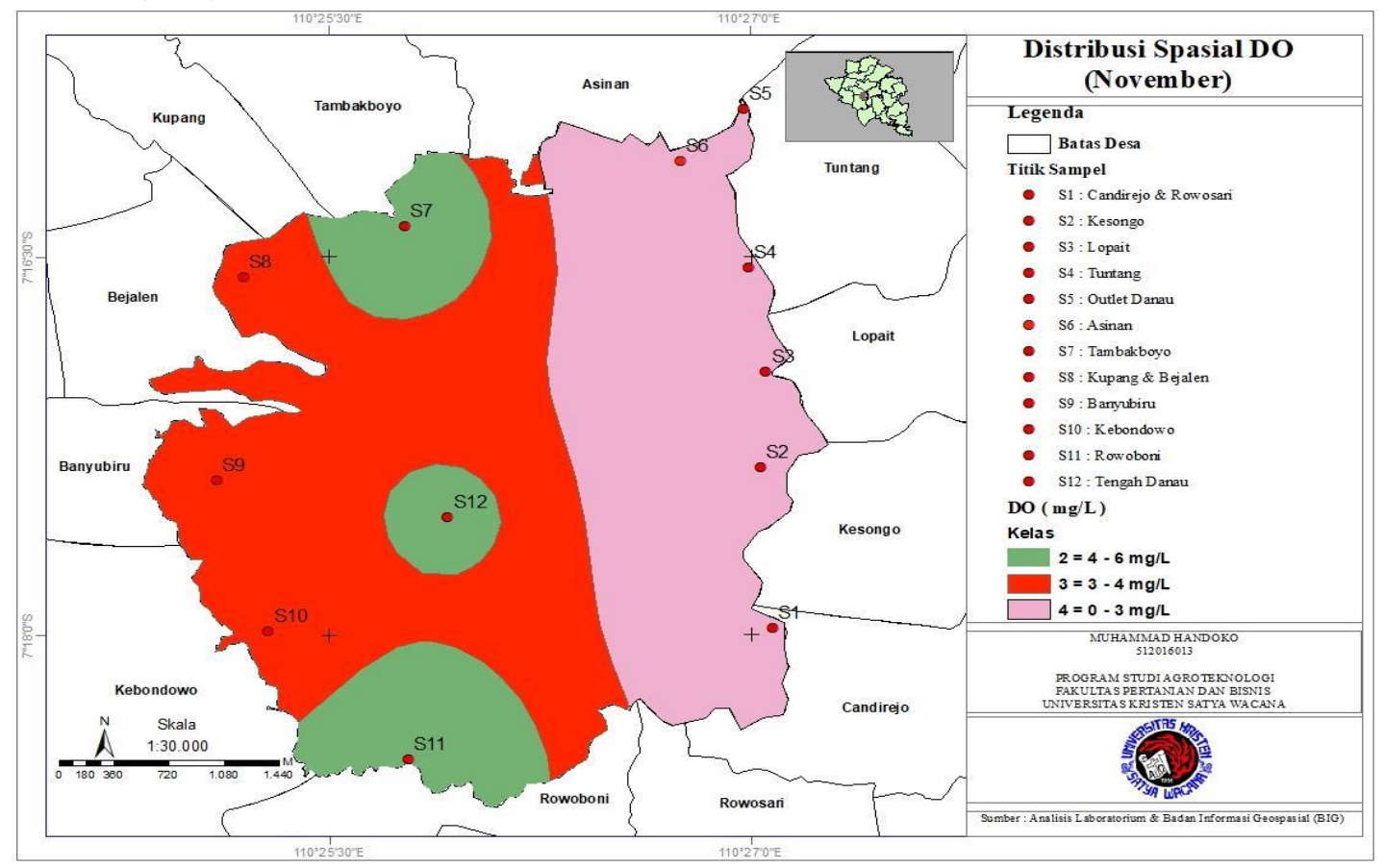

Source: (Data Processing)

Figure 4. Results of Dissolved Oxygen (DO) Spatial Distribution in November 
Based on Government Regulation no. 82 of 2001 concerning Water Quality Management and Water Pollution Control, quality standards for class I DO parameters $>6 \mathrm{mg} / \mathrm{L}$, class II 4-6 mg/L, class III 3-4 $\mathrm{mg} / \mathrm{L}$, and class IV $0-3 \mathrm{mg} / \mathrm{L}$. When viewed in Figures 2, 3, and 4 and explained above, the magnitude of the DO value when the movement from station 1 to the next station is increasingly changing, it is influenced by the diffusion speed of oxygen from the air, depending on several factors such as water turbidity, temperature, water mass movement, currents, waves and tides (Sahrijanna and Septiningsih, 2017).

The higher the DO, the better the water will be, and do it at a relatively higher low temperature (Novianti, 2018). Temperature also affects the ability of water to absorb oxygen from the air (Effendi and Wardiatno, 2015). This ability affects the decomposition capability of organic matter by microbes. Temperature and dissolved oxygen have opposite directions, but dissolved oxygen levels on the surface are generally higher due to the diffusion process between water and free air and photosynthesis (Gemilang et al, 2017). DO is the concentration of dissolved oxygen in water, its presence is essential for maintaining various forms of biological life in water and the effects of waste disposal in the BODy of water are largely determined by the balance of oxygen (Effendi and Wardiatno, 2015). In S5, S7, S10, and S12 DO values experience ups and downs in each month, where at this point in September to October do values increase, Device (2014) states that the increase in dissolved oxygen value is caused because the water hyacinth plant has performed absorption process through the root.

While in October to November, S5, S7, S10, and S12 decreased, in this month there was rain, therefore, household waste is very quickly spread through the flow of times so that there is turbidity on the surface of the water and flows on the Lake Outlet
(S5) and spread in the Middle of the Lake (S12) carried by currents and waves (Sahannarij and Septiningsih, 2017). In S1, S2, S3, S4, S6, S8, and S9 decreased in September to November, according to Sari and Wijaya (2019) the low DO value due to the process of photosynthesis by phytoplankton at the river base is so low that oxygen levels dissolved in water become low. This can affect the performance and survival of biological communities, and below $2 \mathrm{mg} / \mathrm{L}$ can lead to fish death (Yulistia et al., 2018). At this point, in October and November, there is the dredging of the lake so that the water becomes murky which makes it difficult for light to enter the water so that the process of photosynthesis conducted by phytoplankton is disrupted and causes DO to below, according to Utami (2012) light is the main need for phytoplankton in the process of photosynthesis. In September 2020 DO measurement starts at $06.24-14.39$, October 2020 starts at $06.17-09.43$ and November 2020 starts at $06.26-11.17$.

The average do and temperature measurement time starts at 06.00 where sampling of the starting point is done when sunlight begins to enter the water but the further to the next point the sun begins to scorch, this affects the process of photosynthesis to produce oxygen in the waters (Patty, 2014). According to Patty (2014) said that the main source of oxygen in the waters other than the process of oxygen diffusion from the air is from the photosynthesis of phytoplankton, so the high oxygen content in the waters will characterize the high abundance of phytoplankton organisms in those waters. Therefore, the correlation of temperature to dissolved oxygen on the surface of the water has a direct relationship, where when the temperature rises then the dissolved oxygen will increase, thus the increase in temperature in the waters will cause a decrease in the level of dissolved oxygen in the waters (Agustiningsih, 2012). The results showed the average value of DO values $S 1$, S2, S3, S4, S6, S8, and S9 each month 
decreased therefore if seen from the criteria of DO then Rawa Pening Lake water does not meet the criteria as a raw material for drinking water (class I). Spatial and Temporal Distribution of Biochemical Oxygen Demand (BOD)

The average BOD concentration in September 2020 was $3.16 \mathrm{mg} / \mathrm{L}$ with a maximum concentration of $7.4 \mathrm{mg} / \mathrm{L}$ in Lopait (S3), the minimum concentration of $0.2 \mathrm{mg} / \mathrm{L}$ di Kebondowo (S10), and Central Lake (S12). From Figure 5 it appears that BOD score in September, there are 5 points not included in the class (below the class quality standard), 2 points including class I, 3 points including class II, and 2 points including class III.

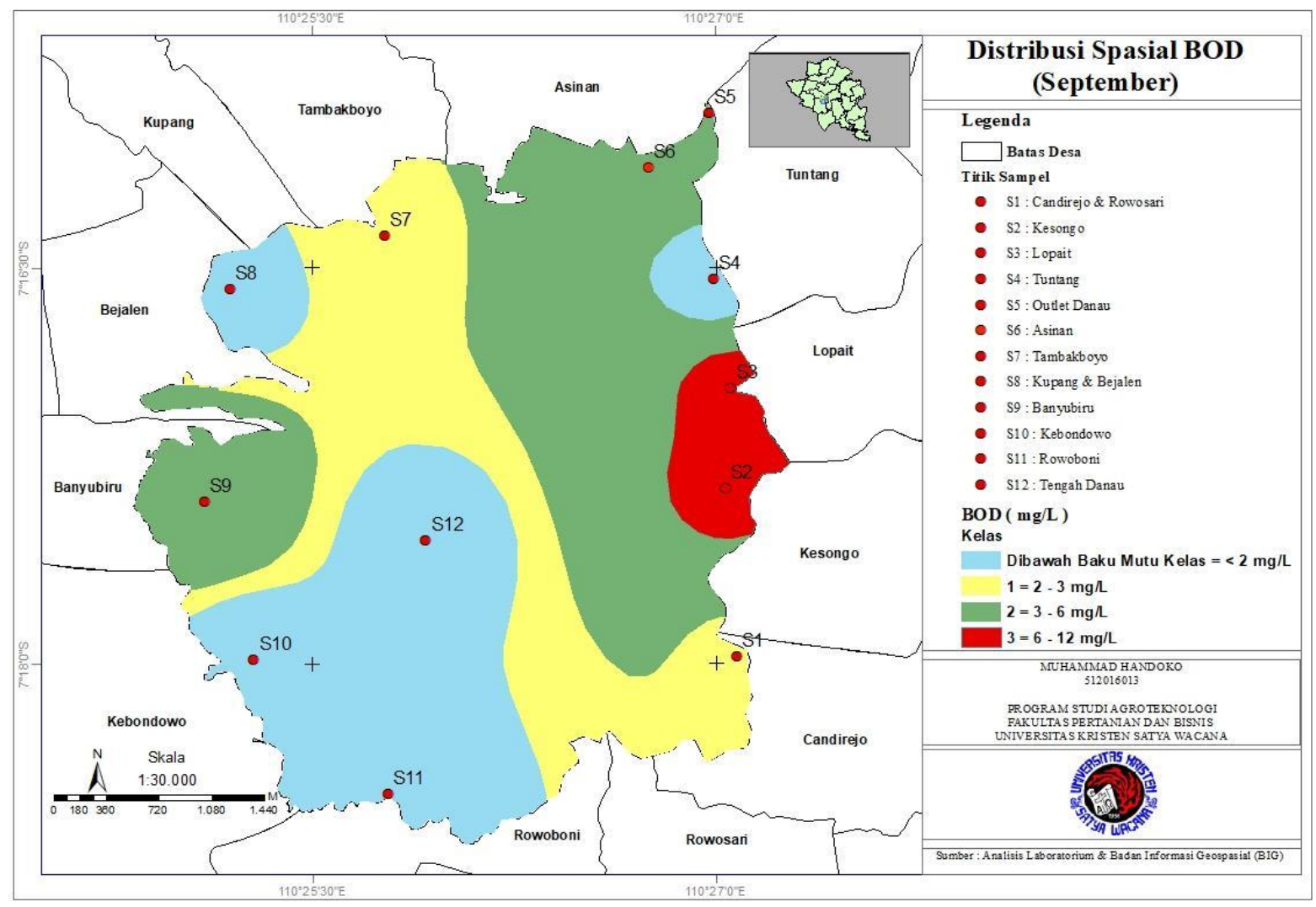

Source: (Data Processing)

Figure 5. Results of Spatial Distribution of Biochemical Oxygen Demand (BOD) in September

The average BOD concentration in October 2020 was $2.6 \mathrm{mg} / \mathrm{L}$ with a maximum concentration of $7.1 \mathrm{mg} / \mathrm{L}$ in Tambakboyo (S7), minimum concentration $0.1 \mathrm{mg} / \mathrm{L}$ di Tuntang (S4). From Figure 6 it appears that
BOD values in October, there are 7 points not included in the class (below the class quality standard), 1 point including class I, 2 points including class II, and 2 points including class III. 


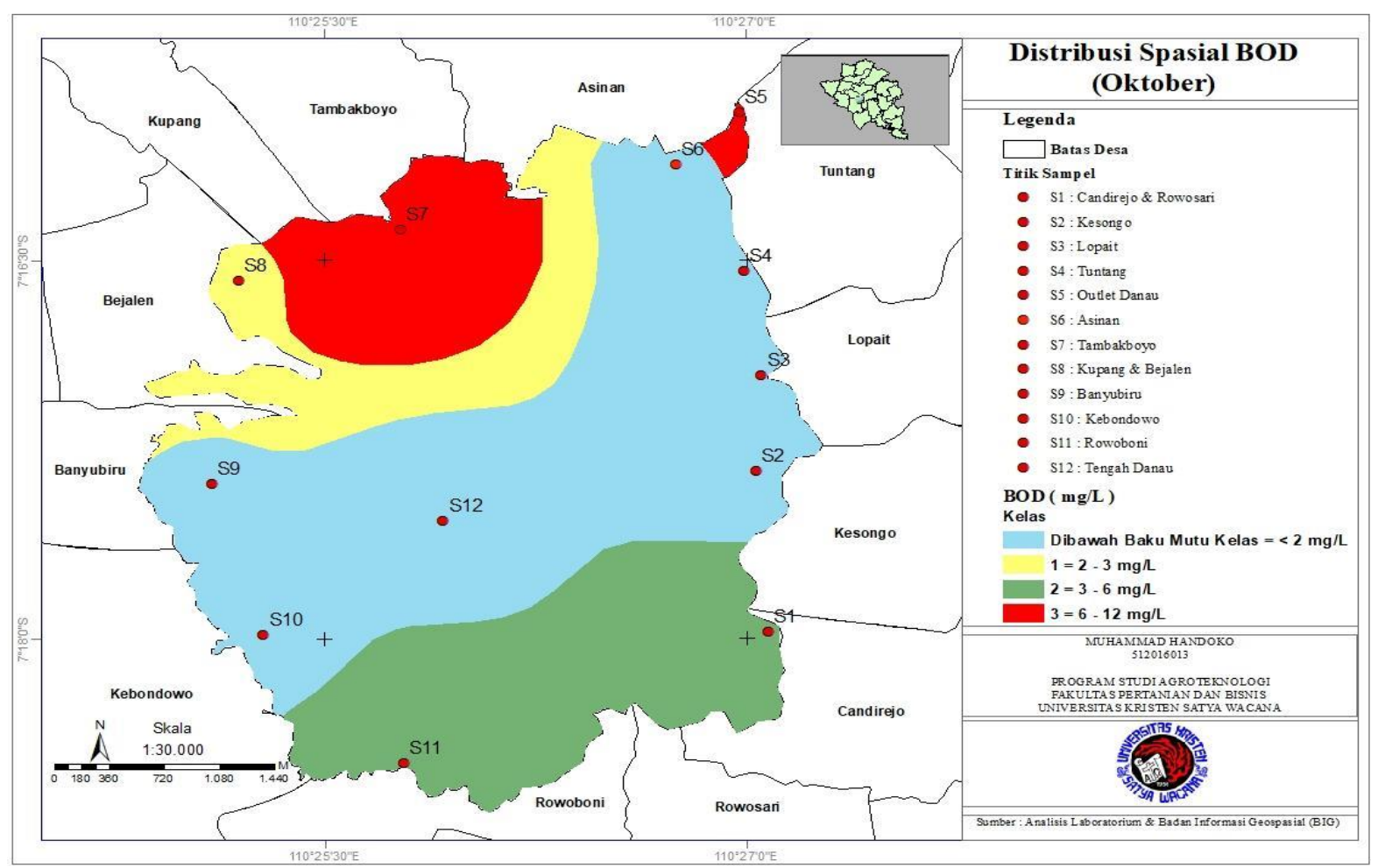

Source: (Data Processing)

Figure 6. Results of Spatial Distribution of Biochemical Oxygen Demand (BOD) in October

Average BOD concentrations have decreased from $2.6 \mathrm{mg} / \mathrm{L}$ in October to $1.53 \mathrm{mg} / \mathrm{L}$ in November, with a maximum concentration of $3.9 \mathrm{mg} / \mathrm{L}$ in Rowoboni (S11) and a minimum concentration of 0.1 $\mathrm{mg} / \mathrm{L}$ in Kesongo (S2). From Figure 7, it

appears that BOD scores in November, 8 points are not included in the class (below the class quality standard), 2 points including class I, and 2 points including class II.

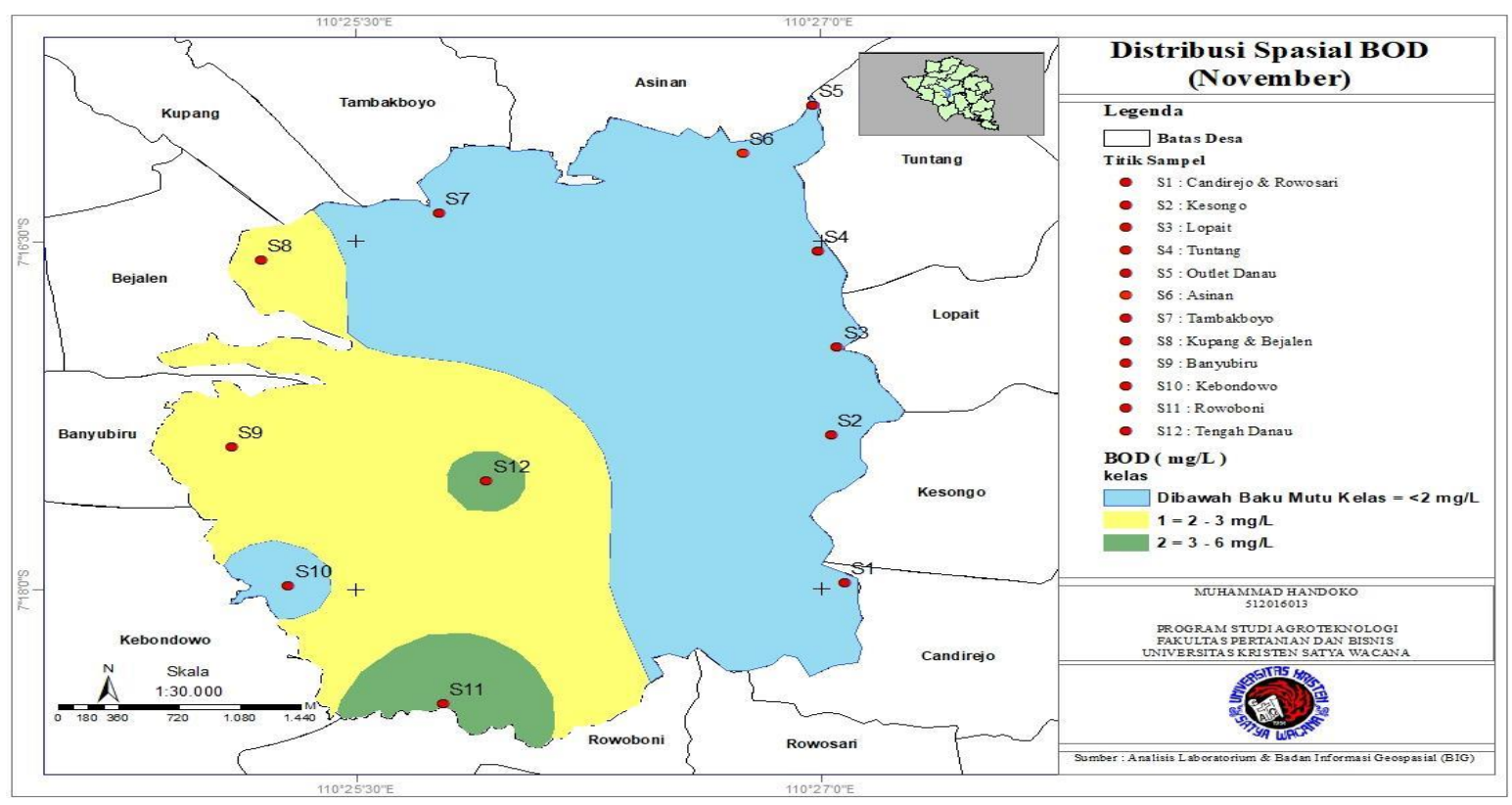

Source: (Data Processing)

Figure 7. Results of Spatial Distribution of Biochemical Oxygen Demand (BOD) in November 
Based on PP No. 82 of 2001, the quality standard for class I BOD parameters is $2-3 \mathrm{mg} / \mathrm{L}$, Class II is $3-6$ $\mathrm{mg} / \mathrm{L}$, class III is $6-12 \mathrm{mg} / \mathrm{L}$ and class IV is $<12 \mathrm{mg} / \mathrm{L}$. If seen in Figures 5, 6, and 7 and the explanation above, the activities carried out by the community at each station are used as water hyacinth handicrafts, tourism places, fish farming activities, floating net grazing, fishing, and cleaning water hyacinth. BOD values in September 2020 at S2 $(7.1 \mathrm{mg} / \mathrm{L})$ and S3 $(7.4 \mathrm{mg} / \mathrm{L})$, BOD values in October 2020 at S5 (6.8 $\mathrm{mg} / \mathrm{L})$ and $\mathrm{S} 7(7.1 \mathrm{mg} / \mathrm{L})$ have passed the grade II water quality standard threshold values. According to Saputra et al (2017). The high BOD value indicates that the amount of oxygen needed by microorganisms to oxidize organic matter in the water is high, this means that in the water there is already an oxygen deficit. The result of the disposal of the rest of KJA feed is an organic waste that can rot or degrade by microorganisms, so this will increase the population of microorganisms in the water. According to Pamungkas (2016) stated that BOD can reflect the level of pollution of a BODy of water by organic waste, the higher the value of BOD means the greater the level of pollution and other factors that affect the value of BOD include: the type of waste, water temperature, and overall water conditions, besides BOD examination, is needed to determine the pollution burden due to wastewater residents or industry, as well as to design the right biological treatment systems for the polluted water.

In S1, S5, S7, S8, S11, and S12 BOD values experience ups and downs every month, where at this point in SeptemberOctober BOD values have increased, Muthifah et al (2018) stated that BOD value is suspected of fish farming activities and domestic waste in lake waters that cause the content of organic matter to be high. where S1, S7, and S8 there are flow times and close to fertilization, while for S5, S11, and S12 there are fish farming activities and peatland miners' activities that cause BOD to be high. Judging from the opinion of Tatangindatu et al (2011) the high BOD is due to the amount of oxygen that microbes need to oxidize organic matter in high waters. The results of observations made at the time of the study there are remaining fish feed that is not cleaned in the waters of Rawa Pening Lake, Tobing et al (2014), and Yuningsih et al (2014), stated that the rest of the feed can cause an increase in organic matter in the water increased, due to the buildup of organic matter in the waters that cause the decomposition process by decomposition organisms are increasing.

The greater BOD concentration of water, indicating the concentration of organic matter in the water is also high (Ali et al., 2013). BOD values in S4 and S9 each month decreased (low). According to Muthifah et al (2018), the low value of BOD is influenced by the decrease in temperature value, resulting in lower BOD levels. Also, the low value of BOD is due to the lack of pollutant sources in S4 and $\mathrm{S} 10$. The results showed the average value of BOD at points S1, S5, S7, S8, S11, and $\mathrm{S} 12$ each month increased therefore if seen from the criteria of BOD then the water of Rawa Pening Lake does not meet the criteria as raw materials for drinking water (class I). Based on its BOD concentration, reawakening lake water is no longer suitable when used for drinking raw water and recreational facilities, but aquaculture activities show no problem.

\section{CONCLUSIONS}

Do score in September 2020 there are 8 points including class I, 3 points including class II, and 1 point including class IV, in October 2020 there are 4 points including class I, 2 points including class II, 1 point including class III, and 5 points including class IV, as of November 2020 there are 3 points included in class II, 3 points including class III and 6 points including class IV. Monthly DO changes are caused by household waste and lake dredging activities. Then the BOD score in 
September 20202 points include class I, 3 points including class II, 2 points including class III, and 5 points excluding classes, In October 2020 there was 1 point included in class I, 2 points including class II, 2 points including class III and 7 points not included in the class, while in November 2020 there were 2 points included in class I, 2 points including class II and 8 points not included in the class. BOD changes every month due to the rest of fish feed and household waste.

\section{RECOMMENDATION}

Based on the results of the study, the value of DO and BOD in each month decreased so that the value of $\mathrm{DO}$ and BOD in Rawa Pening Lake has been included in the category of danger, therefore researchers recommend to; increase wastewater management that goes directly into the river and increase socialization to the community of waste and waste problems.

\section{REFERENCE}

Agung Setianto dan Tamia Triandini. 2013. Comparison of Kriging and Inverse Distance Weighted (IDW) Interpolation Methods In Lineament Extraction And Analysis. J. SE Asia Appl. Geol 5 (1), (2013) page. 21-29. DOI: https://doi.org/10.22146/jag.7204 Available at https://jurnal.ugm.ac.id/jag/article/ view/7204/5643

Agustiningsih, Dyah. 2012. Kajian Kualitas Air Sungai Blukar Kabupaten Kendal dalam Upaya Pengendalian Pencemaran Air Sungai. Tesis. Program Magister Ilmu Lingkungan Program Pasca Sarjana, Universitas Diponegoro, Semarang. (Online) available at http://eprints.undip.ac.id/36856/1/ Naskah_Tesis.pdf accessed at16 Desember 2020.

Agustira, R., Lubis, Kemala S., dan Jamilah. 2013. Kajian Karakteristik
Kimia Air, Fisika Air Dan Debit Sungai Pada Kawasan Das Padang Akibat Pembuangan Limbah Tapioka. Jurnal Online Agroekoteknologi 1 (3) Juni (2013) 615-625. ISSN: 2337- 6597. DOI: 10.32734/jaet.v1i3.2939. Available at

https://www.neliti.com/id/publicati ons/95191/kajian-karakteristikkimia-air-fisika-air-dan-debitsungai-pada-kawasan-das-pada

Ali, A., Soemarno dan Mangku, P. 2013. Kajian Kualitas Air Dan Status Mutu Air Sungai Metrodi Kecamatan Sukun Kota Malang. Jurnal Bumi Lestari, 13 No. 2, Agustus 2013, hlm. 265-274. ISSN 2527-6158. Available at https://ojs.unud.ac.id/index.php/blj e/article/view/6643

Ardhiani, R, R. 2016. Oxidation Ditch Alga Reactor Dalam Pegolahan Zat Organik Limbah Grey Water. (Online) available at https://dspace.uii.ac.id/bitstream/h andle/123456789/2667/08\%2 0naskah\%20publikasi.pdf accessed at14 desember 2020.

Cowx, Ian G. 2002. Principles and Approaches to the Management of Lake and Reservoir Fisheries dalam buku Management and Ecology of Lake and Reservoir Fisheries. edited by I.G. Cowx. page. 376-393.

Dinas Peternakan dan Perikanan Kabupaten Semarang. 2007. Kajian Potensi Sumberdaya Perikanan Rawa Pening Kabupaten Semarang 2007. Laporan Akhir. PT. Astri Bumi Semarang

Effendi, H., Romanto, dan Wardiatno, Y. 2015. Water quality status of Ciambulawung River, Banten Province, based on pollution indeks and NSF-WQI. Procedia Environmental Sciences, 24 ( 2015 ) 228-237. DOI: 10.1016/j.proenv.2015.03.030 
available

at

https://www.researchgate.net/publi cation/274460102_Water_Quality_ Status_of_Ciambulawung_River_ Banten_Province_Based_on_Pollu tion_Index_and_NSF-WQI

Gemilang, Wisnu A., Rahmawan, Guntur A., dan Wisha, Ulung J.2017. Kualitas Perairan Teluk Ambon Dalam Berdasarkan Parameter Fisika dan Kimia pada Musim Peralihan I. EnviroScienteae 13 (1), April 2017 hlm. 79-90. ISSN: 2302-3708. Available at https://ppjp.ulm.ac.id/journal/index .php/es/article/view/3518/3047

Heriza, D., Abdi Sukmono, A., dan Bashit, N. 2018. Analisis Perubahan Kualitas Perairan Danau Rawa Pening Periode 2013, 2015 dan 2017 Dengan Menggunakan Data Citra Landsat 8 Multitemporal. Jurnal Geodesi Undip, 7 (1), (2018) hlm. 79-89. ISSN : 2337-845X. Available at https://ejournal3.undip.ac.id/index. php/geodesi/article/view/19311/18 325

Kementerian Lingkungan Hidup (KLH). 2011. Gerakan Penyelamatan Danau (GERMADAN) Rawapening. Kementerian Lingkungan Hidup, Jakarta.

Machbub, B., Suwanto, A., Harahap, Titi N., Manurung, H., Rachmiati, Inge RS., Rustad, Wahyu C. 2012. Daya Tampung Beban Pencemaran Air dan Zonasi Danau Rawapening. Deputi Bidang Pengendalian Kerusakan Lingkungan Dan Perubahan Iklim : Kementerian Lingkungan Hidup

Muthifah, L., Nurhayati., Utomo, Kiki U. 2018. Analisis Kualitas Air Danau Kandung Suli Kecamatan Jongkong Kabupaten Kapuas Hulu. Jurnal Teknologi Lingkungan Basah, 6 (1), (2018) hlm. 1-10. ISSN: 2622-2884. Available at https://jurnal.untan.ac.id/index.php /jmtluntan/article/view/25315/7567 6576485

Novianti, D. 2018. Analisis Spasial Kualitas Air Tanah dan Air Permukaan Akibat Aktivitas di Sekitar TPA Sampah Terjun Kota Meda. Skripsi. Departemen Teknik Lingkungan. Universitas Sumatera Utara. Available at https://repositori.usu.ac.id/handle/1 $23456789 / 9225$ accessed at14 Desember 2020

Pamungkas, Oktafeni A. 2016. Studi Pencemaran Limbah Cair Dengan Parameter BOD5 Dan Ph Di Pasar Ikan Tradisional Dan Pasar Modern Di Kota Semarang. Jurnal Kesehatan Masyarakat, 4 (2) April (2016) 166-175. ISSN: 2356-3346. Available

at https://ejournal3.undip.ac.id/index. php/jkm/article/view/11942/11596

Patty, Simon I. 2015. Karakteristik Fosfat, Nitrat Dan Oksigen Terlarut Di Perairan Selat Lembeh, Sulawesi Utara. Jurnal Pesisir dan Laut Tropis, 2 (1) (2015) 1-7. DOI: https://doi.org/10.35800/jplt.3.2.20 15.9581. Available at https://ejournal.unsrat.ac.id/index.p hp/jplt/article/view/9581/9159

Peraturan Pemerintah (PP) RI No. 82 Tahun 2001. Tentang Pengelolaan Kualitas Air Dan Pengendalian Pencemaran Air.

Piranti, A.S., 2014. Input of Nutrient (Nitrogen And Phosphorus) From The Catchment Area Into Rawapening Lake Of Central Java. Prosiding Seminar International Basic Science (IBSC). Jember, Indonesia. Available at https://jurnal.unej.ac.id/index.php/ prosiding/article/view/4133/3826 accessed at 16 Desember 2020

Sahrijanna, A., dan Septiningsih, E. 2017. Variasi Waktu Kualitas Air Pada Tambak Budidaya Udang Dengan Teknologi Integrated Multitrophic Aquaculture (IMTA) di Mamuju 
Sulawesi Barat. Jurnal Ilmu Alam dan Lingkunga 8 (16) (2017) 52 57. ISSN: $2549-8819$. Available at

https://journal.unhas.ac.id/index.ph p/jai2/article/view/2991

Salmin. 2005. Oksigen Terlarut (Do) Dan Kebutuhan Oksigen Biologi (BOD) Sebagai Salah Satu Indikator Untuk Menentukan Kualitas Perairan. Oseana 30 (3) (2005) 2126. ISSN 0216-1877. Available at http://oseanografi.lipi.go.id/dokum en/oseana_xxx(3)21-26.pdf

Saputra Wayan RR., Restu, W., dan Pratiwi, Made A. 2017. Analisis Kualitas Air Danau Sebagai Dasar Perbaikan Manajemen Budidaya Perikanan Di Danau Buyan Kabupaten Buleleng, Provinsi Bali. Jurnal Ecotrophic 11 (1) (2017) 17. ISSN: 2503-3395. Available at https://ojs.unud.ac.id/index.php/EC OTROPHIC/article/view/31616/19 240

Sari, Enda K., dan Wijaya, Oki E. 2019. Penentuan Status Mutu Air dengan Metode Indeks Pencemaran dan Strategi Pengendalian Pencemaran Sungai Ogan Kabupaten Ogan Komering Ulu. Jurnal Ilmu Lingkungan, 17 (3) (2019) 486491. ISSN 1829-8907. DOI:10.14710/jil.17.3.486-491.

Available at https://ejournal.undip.ac.id/index.p hp/ilmulingkungan/article/view/25 $562 /$ pdf

Susana, T. 2009. Tingkat Keasaman (Ph) Dan Oksigen Terlarut Sebagai Indikator Kualitas Perairan Sekitar Muara Sungai Cisadane. Jurnal Teknik Lingkungan 5 (2) Desember (2009) 33-39. ISSN: 1829-6572. Available at http://puslit2.petra.ac.id/ejournal/in dex.php/jtl/article/view/17772/176 88

Sutrisno, Alfred J., Kaswanto, Regan L., dan Arifin, Hadi S. 2018. Spatial and temporal distribution of nitrate concentration in Ciliwung River, Bogor City. IOP Conf. Ser.: Earth Environ. 179 (2018) 012039. DOI: 10.1088/1755-1315/179/1/012039 available at https://iopscience.iop.org/article/10 .1088/17551315/179/1/012039/pdf

Tahir, Rovila B. 2016. Analisis Sebaran Kadar Oksigen (O2) Dan Kadar Oksigen Terlarut (Dissolved Oxygen) Dengan Menggunakan Data In Situ dan Citra Satelit Landsat 8 (Studi Kasus: Wilayah Gili Iyang Kabupaten Sumenep). Tesis. Program Magister Bidang Keahlian Teknik Geomatika Jurusan Teknik Geomatika, Fakultas Teknik Sipil Dan Perencanaan Institut Teknologi Sepuluh Nopember Surabaya, Surabaya. (Online) available at http://repository.its.ac.id/71318/1/3 514201003-master\%20theses.pdf accessed at 18 Desember 2020

Tatangindatu, F., Kalesaran, O,. dan Rompas, R. 2013. Studi Parameter Fisika Kimia Air pada Areal Budidaya Ikan di Danau Tondano, Desa Paleloan, Kabupaten Minahasa. Jurnal Budidaya Perairan. 1 (2) (2013) 8 - 19. DOI: 10.35800/bdp.1.2.2013.1911.

Available at https://ejournal.unsrat.ac.id/index.p $\mathrm{hp} / \mathrm{bdp} /$ article/view/1911

Tobing, Sudoyo L.; Barus, Ternala A.; Desrita. 2014. Analisis Kualitas Air Akibat Keramba Jaring Apung di Danau Toba Dusun Sualan Desa Sibaganding Kabupaten Simalungun Sumatra Utara. Skripsi. Program Studi Manajemen Sumberdaya Perairan, Fakultas Pertanian, Universitas Sumatra Utara. (Online) available at http://repository.usu.ac.id/bitstrea m/handle/123456789/50167/Cover 
.pdf? sequence $=6 \&$ isAllowed $=\mathrm{y}$ accessed at18 Desember 2020

Utami Nopi P., Suherman, Yuniarti M. dan Haetami, K. 2012. Pertumbuhan Chorella sp. yang Dikultur Pada Perioditas Cahaya yang Berbeda. Jurnal Perikanana dan Kelautan. 3 (3) (2012) 237244. ISSN: 2088-3137. Available at http://jurnal.unpad.ac.id/jpk/article /view/1467/1465

Xie, Y., Chen B., dan Lei M. 2011. Spatial Distribution of Soil Heavy Metal Pollution Estimated By Different Interpolation Methods: Accuracy And Uncertainty Analysis. Chemosphere 82 (3) (2011) 468-476. DOI: 10.1016/j.chemosphere.2010.09.04 5. Available at https://www.sciencedirect.com/sci ence/article/abs/pii/S00456535100 1060X

Yaxin, C., Ruimin L., Chengchun, S., Peipei, Z., Chenghong, F., dan Zhenyao, S,. 2012. Spatial And Temporal Variations In Nitrogen And Phosphorous Nutrients In The Yangtze River Estuary Marine Pollution. Bulletin 64 (10) Agustus (2012) 2083-2089. DOI: $10.1016 /$ j.marpolbul. 2012.07.020. Available at https://europepmc.org/article/med/ 22910333

Yulis, Putri AR., Desti, Asyti Febliza. 2018. Uji Kualitas Air Limbah Aktivitas Penambangan Emas Tanpa Izin (PETI) di Kabupaten
Kuantan Singingi Riau. Proceeding Semnas. Pendidikan Biologi, Universitas Islam Riau, Riau.

Yulistia, E., Fauziyah, S., dan Hermansyah, H. (2018). Assessment of Ogan River Water Quality Kabupaten Oku Sumsel by NSFWQI Method. Indonesian Journal of Fundamental and Applied Chemistry 3 (2) (2018) 5458. DOI: 10.24845/ijfac.v3.i2.54. Available at http://ijfac.unsri.ac.id/index.php/ijf ac/article/view/99/55

Yuningsih, Hartati D., Soedarsono, P., dan Anggoro, S. 2014. Hubungan bahan organik dengan produktivitas perairan pada kawasan tutupan eceng gondok, perairan terbuka dan keramba jaring apung di Rawa Pening Kabupaten Semarang Jawa Tengah. Diponegoro Journal of Maquares 3(1) (2014) 37 - 43. DOI: $\quad 10.14710 /$ marj.v3i1.4284. Available at https://ejournal3.undip.ac.id/index. $\mathrm{php} / \mathrm{maquares} /$ article/view/4284/41 38

Zulfia, N., dan Aisyah. 2013. Status Trofik Perairan Rawapening Ditinjau Dari Kandungan Unsur Hara (No3 Dan Po4) SertaklorofilA. BAWAL, Vol. 5 (3) Desember (2013) 189-199. DOI:10.15578/bawal.5.3.2013.189 -199. Available at http://ejournalbalitbang.kkp.go.id/index.php/baw al/article/view/639/646 